\title{
Tieteen politisoitumisesta - ja katsaus kuluneeseen kahteen vuoteen
}

Tämän pääkirjoituksen ja numeron (4/2020) myötä päättyy allekirjoittaneiden kaksivuotinen kausi Politiikka-lehden konehuoneessa. Päätoimituskausi on tarjonnut valaisevan kuvan suomalaisen politiikan tutkimuksen nykytilasta ja trendeistä. Palaamme joihinkin toimituskautemme keskeisiin tunnuslukuihin tekstin loppupuolella, mutta sanottakoon jo tässä yhteydessä muutama yleisempi huomio kokemuksistamme viimeiseltä kahdelta vuodelta.

Ensinnäkin olemme saaneet iloksemme huomata, että suomenkielinen politologinen julkaisutoiminta on edelleen suhteellisen aktiivista ja temaattisesti laaja-alaista. Vaikka yliopistojen rahoitusmallissa tapahtuneet muutokset vaikuttavatkin olevan yhteydessä julkaisutoiminnan vireyteen ja painotuksiin (ks. Seuri ja Vartiainen 2018, 114-115), lienee kotimaisen tiedetoimittamisen jouhevuudella (siedettävä julkaisuviive) sekä ylipäätään halulla osallistua suomenkieliseen ja suomalaista yhteiskuntaa koskevaan tieteenalakeskusteluun vähintään yhtä suuri merkitys. "Ulkomailla" (lue: englanninkielisen) julkaisemisen korostaminen meritoitumisen mittarina ei myöskään vaikuttaisi ainakaan tyystin syrjäyttäneen suomenkielisen tieteenalakeskustelun vetovoimaa (ks. Lahtinen 2019, 282). Politiikka-lehden kohdalla avoimeen sähköiseen julkaisumalliin siirtymisellä ja tutkimustulosten saavutettavuuden parantumisella on varmasti myös oma positiivinen vaikutuksensa edellä mainittuun vireyteen.

Olemme lisäksi pistäneet merkille saamiemme käsikirjoitusten painottumisen varsin tyypilliseen empiristiseen muottiin. Politiikan teoriaan ja käsitteelliseen kehittämiseen sekä oppi- ja aatehistoriaan painottuvat käsikirjoitusehdotukset ovat olleet edellisiin nähden selvästi vähemmistössä. Voi toki olla, että avaukset tällä saralla pyritään esittelemään kotimaisen tieteenalakeskustelun sijasta kernaammin juurikin kansainvälisissä julkaisuissa, jolloin myös julkaisujen potentiaalinen kohderyhmä laajenee.

Kolmannen huomion sekä tämän pääkirjoituksen varsinaisen teeman ammennamme tiedeja yliopistopolitiikkaa käsittelevistä aikaisemmista pääkirjoituksistamme. Niissä olemme pohtineet tiedepolitiikan vaikutuksia tieteellisen julkaisutoiminnan luonteen muutokseen (Poutanen ym. 2019a), yliopiston ja tutkijan muuttuvaa suhdetta (Poutanen ym. 2019b; ks. myös Haukkala 2019), yliopistokritiikin ja kriittisen intellektuellismin alennustilaa (Lahtinen 2019) sekä tutkijan yhteiskunnallisen aseman muutoksia (Poutanen ym. 2020). Yleisesti ottaen pääkirjoituksemme ovat resonoineet viime vuosina voimistuneen laajemman liikehdinnän ja keskustelun kanssa, jossa tieteen ja politiikan suhde on asetettu uudelleentarkastelun kohteeksi.

Tänä vuonna julkaistiin Esa Väliverrosen ja Kai Ekholmin toimittama teos Tieteen vapaus \& Tutkijan sananvapaus (2020: Vastapaino), jossa keskusteltiin myös politiikan ja tutkimuksen suhteesta. Tuntuu luonnolliselta, että nimenomaan politiikan tutkimukseen keskittyvässä lehdessä kiinnitetään huomiota myös politiikan ja tutkimuksen suhteiden näkymiin. Usein ajatellaan, että politiikan ja tieteen välillä tulisi olla tietty ylittämätön veteen piirretty viiva. Väliverronen toteaakin, että "[v]akiintuneen käsityksen mukaan tiedettä ja politiikkaa ei pidä sekoittaa keskenään, sillä se vaarantaa tieteen ja asiantuntijoiden puolueettomuuden" (Väliverronen 2020). 
Tieteen ja politiikan rajat ovat kuitenkin selviä vain teoriassa. Uhkana vaikutetaan ensisijaisesti ymmärrettävän politiikan tuleminen tieteen alueelle. Tällä saattaa esimerkiksi olla rajoittava vaikutus tutkijoiden vapauteen ilmaista itseään. Sama pätee tutkijaan, joka toteuttaa niin sanottua yliopiston kolmatta tehtävää, eli yhteiskunnallista vuorovaikuttamista - erityisesti julkiseen keskusteluun osallistumista. Tutkijoihin kohdistuu kuitenkin merkittäviä paineita, osallistuivat he sitten julkisiin keskusteluihin työnsä puolesta asiantuntijoina tai yksityisinä kansalaisina, joilla on oikeus ilmaista mielipiteensä (Poutanen ym. 2020, 3-4).

Tähän liittyy myös tietopohjaisen päätöksenteon merkitys - tutkijoilta odotetaan yhä enemmän vastauksia poliittiseen tiedontarpeeseen. Tähän tiedontarpeeseen vastaaminen voidaan myös ymmärtää herkästi (puolue)poliittisesti värjääntyneeksi, etenkin kun poliitikot perustelevat päätöksensä tähän tutkimustietoon vedoten. Tämä vahvistaa julkista keskustelua leimaavaa "informaatiohajaannusta", jota vahvistaa puhtaan disinformaation määrän kasvamisen lisäksi myös tapa, jolla poliittisessa keskustelussa tukeudutaan tietoisesti omaan agendaan sopivien lähteiden ja eri kantoja edustavien asiantuntijoiden esille nostamiseen (ks. Juntunen ja Hyvönen 2020, 84-85).

Esa Väliverronen ja Sampsa Saikkonen huomauttavatkin, että valtion rahoitusinstrumenttien puitteissa suomalaisten yliopistojen tiede on jo tietyllä tavalla, sekä suoraan että epäsuorasti, ohjattua (Väliverronen ja Saikkonen 2020). Tähän ovatkin tarttuneet etenkin oikeistopopulistit (Harni 2020, ks. myös Kostiainen 2020; Väliverronen 2020), jotka herkästi liittävät politiikkaa kommentoivan tutkijan siihen yhteiskunnalliseen eliittiin, jota populismi muutenkin vastustaa. Julkiseen keskusteluun osallistuvalle tutkijalle (ja/tai hänen julkaisualustalleen) sataa herkästi välitöntä kritiikkiä, jonka asiallisuuden taso vaihtelee huomattavasti.

Samaan aikaan on tärkeää pohtia myös tieteen vapaaehtoista ja oma-aloitteista astumista politiikan näyttämölle. Donald Trumpin Yhdysvalloissa tiede on ottanut melko voimakkaita kantoja nykyhallintoa vastaan. Yhteiskuntatieteiden osalta tämä ei liene yllättävää, mutta myös yleiset luonnontieteelliset julkaisut ovat viimeaikoina kommentoineet Trumpin hallinnon toimia ja tiedekäsityksiä melko terävästi (Väliverronen 2020). Tutkijat ovat reagoineet avoimen puoluepoliittisesti tilanteeseen, jonka ovat nähneet uhkaavan tiedettä instituutiona. Mikä siis on tieteellisen instituution, kuten tiedelehden, vapaus ottaa poliittisesti kantaa?

Monelle saattaa tuntua vaikealta ymmärtää, mistä on kyse: onko tieteestä tullut yhtäkkiä politiikan jatke? Politiikan tutkijan näkökulmasta näin ei ole. Kyse on pikemminkin siitä, että vastaavia tieteellisiä interventiota politiikkaan ei ehkä ole koettu tarpeelliseksi. Nyt huoli tuntuu kumpuavan siitä, että poliittinen toiminta on vahingoittanut tiedettä, tai että tieteellinen tieto - esimerkiksi ilmastokriisiin vastaamisessa (ks. myös Juntunen ym. 2019) - vaikuttaa tulevan sivuutetuksi kerta toisensa jälkeen. On luonnollista, että tiettyyn aiheeseen etenkin yhteiskuntatieteissä perehtyneet tutkijat näkevät väistämättä myös tarpeen toimia korjatakseen heidän tutkimuksensa epäkohdiksi osoittamia asioita. Tunnetun historiallisen esimerkin tästä tarjoaa ydinaseita vastaan kantaa ottavien tutkijoiden aktiivisuus (Väliverronen 2020; Vuori 2016).

Tutkijuuden ja poliittisen aktivismin yhdistäminen nähdään kuitenkin yhä monelta osin ongelmallisena, tai ainakin riskialttiilta tutkijan oman uskottavuuden kannalta (Kostiainen 2020). Osa ongelmasta liittyy siihen, että tieteen sisäiset konventiot eivät ole selkeitä tiedeyhteisön ulkopuolella. Kyse on myös yksinkertaistetusta käsityksestä tieteellisestä objektiivisuudesta, jonka perusteella tieteen - ja tieteentekijöiden - odotetaan olevan yhteiskunnallisten 
intressien ulkopuolella eläviä puhtaan arvovapaita olioita (ks. myös Seuri ja Poutanen 2020). Pahimmillaan muodollinen objektiivisuus tukahduttaa tutkijan omaa arvopohjaa ja jopa tämän tunteita, sillä monella tutkijalla on henkilökohtainen side hänelle läheisiin asioihin, joita hän myös tutkii (Halme 2020).

Tutkija siirtyy siis kuvaamasta sitä, mitä maailma on, siihen, mitä sen pitäisi olla. Normatiivinen asenne ei kuitenkaan tee sitä tutkimusta, johon tällainen ajattelu (tai politiikkatoimien suositukset) lepäävät, automaattisesti poliittisesti puolueelliseksi. Jännitteisen tilanteesta tekee se, että tutkijat ovat osin sisäistäneet uhan viime vuosien aikana kasvaneesta trendistä, jossa tiede ja tutkimus kyseenalaistetaan poliittisesti motivoituneena hyvin kevyin perustein. Tämä lisää pelkoa siitä, että jos tutkijan puolueettomuudesta ja objektiivisuudesta livetään tai sitä ei kyetä esittämään riittävän vakuuttavasti, syöttää tutkija niin sanotusti suoraan tiede-epäilijöiden lapaan.

Näin ei tule olla. Esa Väliverronen (2020) siteeraa Bruno Latouria todetessaan, että "tiede ei ole politiikkaa", mutta "tiede on politiikkaa toisin keinoin". Tiede ei ole, eikä sen kuulukaan olla, neutraalia havainnointia, vaan myös havainnoidun ja eletyn maailman muokkaamista. Tiede ja tutkimus eivät instituutioina ole tunnetusti vapaita yhteiskunnallisista valtasuhteista, vaikka kuinka voimakkaasti tutkija yrittäisi eristää itseään muodollisen objektiivisuuden käytänteillä. Tästä syystä tieteen ja politiikan suhdetta ruotiva keskustelu kaipaa kipeästi paitsi vivahteikkuutta ja tieteen sisäisten keskustelujen tuntemista, myös vähemmän aktiivisesti keskusteluun osallistuvien tutkijoiden panosta, jotta tiedevastaisen ilmapiirin leviämiseen olisi mahdollista vastata.

Eräs tieteen politisoitumisen merkeistä, varsinkin yhdysvaltalaisessa kontekstissa, ovat viime aikoina mediahuomiota saaneet tiedehuijaukset (engl. science hoax). Niissä huijarit lähettävät ennalta valittujen tieteenalojen journaaleihin sepitettyjä tutkimusraportteja arvioitavaksi ja julkaistavaksi. Tavoitteena on kyseisten journaalien edustamien tieteenalojen sisäisten kontrollikäytänteiden ja tieteenfilosofisten ydinolettamuksien kestämättömyyden paljastaminen. (Ks. Lăzăroiu 2019.) Tavoitteena on "keskustelua herättämällä” viljellä yleistä epäluottamusta kyseisiä tieteenaloja kohtaan.

On tärkeää erottaa (tiede)poliittisesti motivoituneet huijausoperaatiot vakavammin otettavasta tieteentutkimuksesta (ks. eroista Schnabel 1994, 460-462; Epstein, 1990; Väliverronen 2020). Poliittisesti kiistanalaisten motiiviensa lisäksi tiedehuijarit kuormittavat näiden keppostelujen kohteeksi joutuneita tiedeyhteisöjä kohtuuttomasti. Kyse ei siis ole eettisesti tai metodologisesti pätevistä tutkimusasetelmista. Tiedehuijareiden kohteiksi joutuneiden vertaisarvioijien perusteelliset vastaukset datan ja johtopäätöstensä osalta sepitettyihin käsikirjoituksiin viittaavatkin siihen, että huijauskäsikirjoitukset kuormittavat tieteen sisäisiä kontrolliprosesseja erityisen paljon (Lagerspetz 2020/tulossa, 16).

Tiedehuijausten taustalla vaikuttava julkilausumaton käsitys tieteellisen keskustelun edistymisestä vaikuttaakin vinoutuneelta. Virheet ja puutteet kuuluvat olennaisesti tieteen ja tutkimuksen kehitykseen; puutteiden havaitseminen käynnistää usein produktiivisia debatteja. Korjatuksi ja täydennetyksi tuleminen on tästä näkökulmasta tieteentekijälle kunnianosoitus, kunhan debattia käydään keskustelukumppania kunnioittavassa sävyssä. Tutkimukseen kuuluvat olennaisena 
osana myös erilaiset käsitteellis-teoreettiset ja metodologiset avaukset (toimittajakaudeltamme tällaisia esimerkkejä tarjoavat Manneström ym. 2020 sekä Vogt 2019), joiden tavoitteena on tutkimusasetelman tiukan toistettavuuden tai tulosten yleistettävyyden sijasta itsensä tutkimusasetelman asettaminen tiedeyhteisön kriittisen keskustelun kohteeksi. Keppostelu eksploratiivisten avausten kustannuksella on omiaan kaventamaan ilmapiiriä, joka kannustaa uusiin tutkimuksellisiin läpimurtoihin.

Popperilaisessa hengessä tiedettä ja tutkimustyötä voidaan kuvailla "kitkaisena debattina", joka vaatii kehittyäkseen hankauspisteitä. Jonkin tieteenalan edistystä ei ole mahdollista arvioida luomalla valikoitu "läpileikkaava" katse tietyn hetken akateemisiin käytäntöihin. Esimerkiksi Mikko Lagerspetz (2020/tulossa) on tuoreessa tutkimusartikkelissaan osoittanut, että viimeaikaisten tiedehuijausten "onnistumisprosentti" on itse asiassa ollut melko kehno. Laajaa mediahuomiota ovat saaneet lähinnä ne vähemmistöön jäävät "onnistuneet" koepallot, joissa sepitetty artikkeli on lopulta useammallekin kierrokselle edenneen vertaisarviointiprosessin jälkeen päätynyt julkaistavaksi. Näissäkin tapauksissa myönteiseen arviointipäätökseen on yleensä vaikuttanut se, että käsikirjoituksessa tukeuduttiin uskottavaan muotoon sepitettyyn empiiriseen dataan. Kyse ei siis ole ollut mistään laiskasta, koripallotermejä lainataksemme "sukkana sisään" uponneesta heitosta, vaan merkittävästä vaivasta ja ajallisesta panostuksesta "keppostelijoiden" (emt.) osalta.

Tiedehuijauksiin liittyy myös vahva kaksilla korteilla pelaamisen taktiikka: samalla kun huijauksen tulokset esitetään kokonaisia tieteenaloja kyseenalaistavina "paljastuksina", ei omaa "tutkimusta" kuitenkaan haluta nimetä aidoksi tutkimukseksi. Näin tiedehuijarit kenties pyrkivät välttämään syytökset ilmiselvistä tutkimuseettisistä ongelmista sekä tutkimusdataa koskevista vinoumista (ks. Christensen ja Sears 2018). Esimerkiksi Suomessa Tutkimuseettisen neuvottelukunnan ohjeissa sepittäminen (esimerkiksi tekaistujen havaintojen esittäminen tiedeyhteisölle) on edelleen yksi neljästä tieteellisen vilpin pääkategoriasta (TENK 2013, 8). Tätäkin taustaa vasten on selvää, kuten osa tiedehuijareista on suoraan myöntänytkin, että toimintaa ohjaa poliittiset motiivit.

On mielenkiintoista huomata, että vastaavanlainen kaksoisstandardien logiikka on tuttu myös poliittiseksi trollaamiseksi kutsutun ilmiön taustalta (ks. Ampuja ja Poutanen 2020). Aivan kuten poliittisen somesfäärin trollaajat, myös tiedehuijarit pyrkivät ikään kuin nostamaan itsensä nimeämänsä valtavirtakulttuurin yläpuolelle. Yhtäältä osoitetaan tietyn ryhmän (poliittinen tai tieteellinen) toiminta naurunalaiseksi tai muutoin kyseenalaiseksi, mutta toisaalta esitetään, että oma (poliittinen tai tieteellinen) toiminta eroaa tästä positiivisesti aidoksi ymmärrettynä politiikkana tai tiedepoliittisena kantana. Vastaavasti voidaan pyrkiä korostetusti osoittamaan, että joku muu toimija on ideologisesti motivoitunut, mutta että itse ei ole. Kuten poliittisen trollaamisen kohdalla, tavoitteena on herättää yleistä epäluuloa sekä myrkyttää tiettyjä tutkimusaloja koskevaa keskustelua. Kun poliittinen trollaaja ensin käyttää mielipiteen ilmaisun vapauttaan, saattaa hän tämän jälkeen kehystää tietoisesti aiheuttamansa närkästyksen osoituksiksi siitä, että tämän ilmaisunvapautta pyritään rajoittamaan. Vastaavia piirteitä on ollut havaittavissa myös tiedehuijausten jälkilöylyissä (ks. esim. Flaherty 2019). 
Itseäänkorjaavuuden perustavan normin ja sitä kannattelevan vertaisarviointikäytännön häikäilemätön kaappaaminen "tiedekeppostelujen" performansseihin tekee hallaa koko tiedeinstituution uskottavuudelle. Tämä on erityisen huolestuttava piirre aikana, jolloin tutkitun tiedon asema yhteiskunnallisessa keskustelussa on muutoinkin asetettu moninaisen paineen alaiseksi. Kysymys tieteen sisäisten kontrollikäytänteiden luonteesta ja integriteetistä on kuitenkin tärkeä ja arvokas.

Yksi tapa lisätä ymmärrystä tieteen ja tutkimuksen sisäisistä kontrolliprosesseista on tuoda näkyviin niihin liittyviä tunnuslukuja. Esimerkiksi allekirjoittaneiden Politiikka-lehden toimituskaudella (2019-2020) olemme vastaanottaneet 37 ja julkaisseet 20 A1-julkaisuluokan käsikirjoitusta (osa vastaanottamistamme käsikirjoituksista ovat tätä kirjoittaessa edelleen vertaisarviointiprosessissa). Toimituksellisella päätöksellä olemme hylänneet seitsemän käsikirjoitusta (osa näistä oli laadukkaita, mutta soveltuivat selvästi paremmin muiden lehtien julkaisuohjelmiin), minkä lisäksi vertaisarviointiprosessit ovat tuottaneet hylkäävän päätöksen viiden käsikirjoituksen kohdalla. Olemme kokeneet tärkeäksi tarjota sisällöllistä ja muodollista palautetta kaikille niillekin käsikirjoitusehdokkaille, jotka lopulta tulivat hylätyiksi. Kukin voi tahoillaan arvioida tällaisen toiminnan mielekkyyttä sen jälkeen, jos osa hylätyistä, mutta kuitenkin perehtymistä vaatineista käsikirjoituksista rakentavine palautteineen osoittautuisi tiedehuijauksia tuottavien tahojen kepposiksi.

Alkuperäiskäsikirjoitusten lisäksi olemme julkaisseet kahdeksan pääkirjoitusta (tämä mukaan lukien), 17 keskustelua-käsikirjoitusta sekä 16 kirja-arviota. Toimituskautemme lomaan osui myös suru-uutisia, kun saimme kuulla useammankin suomalaisen politologipioneerin menehtymisestä. Saimme toimituskautemme kuluessa kunnian julkaista Tuomo Martikaisen (1/2019), Ilkka Heiskasen (2/2019) ja Olavi Borgin (1/2020) muistokirjoitukset. Sen lisäksi, että Politiikka-lehti siirtyi toimituskautemme kuluessa kokonaisuudessaan avoimeksi sähköiseksi julkaisuksi, on lehti myös liittynyt doi-tunnusjärjestelmään ja lisännyt näkyvyyttään sosiaalisessa mediassa (muistathan seurata lehteä Facebookissa ja Twitterissä). Toimittajan tehtävissä tutkija joutuu ja pääsee tutustumaan monenlaisiin uusiin haasteisiin - toimittajan työ ei ole "vain" artikkelien toimittamista. Lisäksi fyysisenä tuotteena on jatkanut Politiikka-lehden vuosikerta, joka julkaistaan joulukuussa viimeisen numeron jälkeen, ja joka on Valtiotieteellisen yhdistyksen jäsenille ilmainen kotiin postitettuna.

Vertaisarvioijana toimiminen on akateeminen meriitti, joka ei kuitenkaan juuri meritoi. Vertaisarvioijaksi mukaan lähtemistä motivoineekin enemmän tieteentekemisen kollektiivinen ilo, tieteenalakeskusteluihin osallistumisen mielekkyys sekä oman tieteenalan kehityksen tukemisen kokeminen itseisarvona. Haluammekin kiittää erityisen lämpimästi kaikkia toimituskautemme kuluessa vertaisarviointitehtäviin lähteneitä tutkijoita. Te olette tieteenalakeskustelun etenemisen kriittisin infrastruktuuri! Olemmekin ilolla tervehtineet sitä, että vertaisarviointiin lähdetään edelleen innostuneesti mukaan. Saimme edelleen selvästi todennäköisemmin myönteisen kuin kielteisen vastauksen vertaisarviointipyyntöihimme. Myös vertaisarvioiden laatu ja perehtyneisyys ovat olleet kiitettävällä tasolla.

Samalla haluamme esittää kiitoksemme myös Politiikka-lehteen viimeisen kahden vuoden aikana kirjoittaneille - myös teille, joiden käsikirjoitukset eivät lopulta lehdessämme tulleet julkaistuksi. Olette omalta osaltanne olleet edistämässä tieteenalan keskustelua. Kiitokset lähtevät luonnollisesti myös lehden lukijoille, joita onkin avoimeksi julkaisuksi siirtymisen myötä 
entistä enemmän, myös tiedeyhteisön ulkopuolelta. Lopulta haluamme kiittää myös Tieteellisten seurain valtuuskuntaa toimivan julkaisualustan tarjoamisesta sekä toimitusprosessin (painotetun kärsivällisestä) teknisestä tuesta, ja Valtiotieteellistä yhdistystä luottamuksesta saada toimia Suomen johtavan politiikan tutkimuksen alan tiedelehden päätoimittajina.

Vuoden 2020 viimeisessä numerossa julkaisemme kolme alkuperäisartikkelia, yhden keskustelua-kirjoituksen sekä yhden kirja-arvion.

Minna Sirnö kirjoittaa ensimmäisessä vertaisarvioidussa artikkelissa politiikan, taiteen ja kulttuurin suhteesta. Poliitikkojen väitetään vaikenevan taiteesta ja kulttuurista. Suurimmalla osasta puolueista on silti tarve sanallistaa suhdettaan taiteeseen ja kulttuuriin sekä niiden edistämiseen. Artikkelin laaja tutkimusaineisto koostuu viimeisen kuudenkymmenen vuoden aikana toimineen 48 puolueen 1270 poliittisesta ohjelmasta. Vuosina 1960-2019 toimivista ja vuodesta 1969 lähtien rekisteröityjen puolueiden ohjelmista yhteensä 579:stä löytyy taide- ja kulttuurikirjauksia. Artikkelin tavoitteena on laadullisen ja määrällisen sisällönanalyysin kautta löytää, tunnistaa ja nimetä eri puolueita yhdistävät pitkät linjat, päämäärät ja motiivit taidetta ja kulttuuria koskevissa kirjauksissa poliittisissa ohjelmateksteissä sellaisina kuin ne ohjelmissa esiintyvät eri aikoina.

I nästa artikel Marina Näsman, Fredrica Nyqvist, Marina Lindell, Mikael Nygård och Siv Björklund skriver på svenska för att svara frågan "Vem kan man lita på?": Förändringar i politiskt, institutionellt och socialt förtroende bland äldre i Österbotten. Förtroende för andra människor och samhälleliga institutioner är centralt för den sociala sammanhållningen. Tidigare forskning indikerar att förtroendenivåerna i Finland har sjunkit under de senaste decennierna. Detta har dock inte undersökts specifikt bland den äldre befolkningen, och i synnerhet inte för de äldre i landskapet Österbotten. Syftet med denna studie är att analysera förändringar i politiskt, institutionellt och socialt förtroende från år 2005 till 2016 bland svensk- och finskspråkiga äldre personer i Österbotten. I studien analyseras data från enkätstudien Gerontologisk Regional Databas (GERDA) utförd i Österbotten. Urvalet inkluderade 65- och 75-åringar och bestod av 1545 individer år 2005 och 1742 individer år 2016. Logistisk regression användes för att estimera sannolikheten för att ha högt förtroende enligt studieår och språkgruppstillhörighet i vartdera förtroendemått samtidigt som olika sociodemografiska faktorer inkluderades som kontrollvariabler. Nivån av politiskt och institutionellt förtroende var statistiskt signifikant lägre år 2016 jämfört med 2005 medan ingen signifikant förändring hittades gällande det sociala förtroendet. Resultaten visade också att förändringarna i förtroendemåtten varierade mellan språkgrupperna. De lägre nivåerna av förtroende som hittades i denna studie är ett potentiellt hot mot det sociala kapitalet som i sin tur är en viktig möjliggörare för ett aktivt åldrande och borde därför uppmärksammas och undersökas vidare.

Lisäksi Hanna Tuominen analysoi artikkelissaan Suomen vuoden 2019 jälkipuoliskolle ajoittuneen EU-puheenjohtajakauden arvoulottuvuuksia. Tuomisen tutkimuksen lähtökohtana on selvittää, miksi Suomen puheenjohtajuuskauden profiilia leimasi vahva arvoperustainen painotus sekä miten ja minkälaisia arvoja Suomi lopulta pyrki toimeenpanemaan. Artikkeli pohjautuu asiakirja-aineistoon sekä puheenjohtajakauden valmisteluihin ja toimeenpanoon 
osallistuneiden poliitikkojen, virkahenkilöiden ja kansalaisjärjestöjen edustajien haastatteluihin. Johtopäätöksinään Tuominen esittää, että Suomen arvoperustainen puheenjohtajuus nautti varsin laajaa konsensusta, joka ylsi myös hallituskausien yli. Arvoista nousivat selvimmin esiin oikeusvaltioperiaate, ilmastonmuutoksen hillitseminen, ihmisoikeudet, sukupuolten välinen tasa-arvo sekä sosiaalisen oikeudenmukaisuuden edistäminen. Kyseisten arvojen nostaminen EU-politiikan agendalle vaikuttaa joiltain osin onnistuneen, joskin tutkimuksesta voidaan myös päätellä, että Suomen agendassa painottui jo ennen puheenjohtajuuskautta vahvasti esillä olleet arvoulottuvuudet.

Numerossa 4/2020 julkaistaan myös yksi keskustelua-artikkeli, jossa Jukka Aukia ja Anna Peltomäki kirjoittavat populaarikulttuurin paikoista ja politiikasta hongkongilaisten kung-fuelokuvien pekingiläistymisen välityksellä. Artikkelissa tarkastellaan, miten Manner-Kiinan voimistunut määräysvalta Hongkongin lokaliteettiin ilmenee populaarikulttuurissa. Paikan politiikka tulee esiin kung-fu-elokuvien taustalla vaikuttavissa mannerkiinalaisissa identiteettinarratiiveissa sekä toisaalta nostalgiaelokuvien ilmentämässä kaipauksessa Hongkongin luovutusta edeltävään ajanjaksoon. Hongkongin elokuvateollisuuden lisääntynyt Kiina-johtoisuus oli myös keskeinen peruste demokratia-aktivistien vaatimalle Ip Man 4 -elokuvan boikotille, mikä on puolestaan nähtävä osana laajempaa pekingiläistämistoimia vastustavaa liikehdintää. Aukia ja Peltomäki liittävät Manner-Kiinan ja Hongkongin demokratialiikkeen välisen jännitteen populaarikulttuurin ja paikan suhdetta tarkastelevaan kansainväliseen tutkimuskirjallisuuteen. Kirjoitus korostaa populaarikulttuurin merkitystä politiikan tutkimukselle, mikä konkretisoituu sen kytkennöissä paikkoihin.

Numeron 4/2020 päättää Iida Tammen kirja-arvostelu Saana-Maria Jokisen haastattelututkimukseen pohjautuvasta teoksesta Ä̈̈niä sodasta: Syyrian tie vallankumouksesta suursotaan (2020: Gaudeamus). Arviossaan Tammi katsoo, että Jokisen teos on kattava ja koskettava katsaus yhteen aikamme monimutkaisimmista aseellisista konflikteista. Vuonna 2011 alkanut Syyrian sota on tullut länsimaissa tunnetuksi lähinnä maassa toimivaa ääri-islamistista Isisiä vastaan käytynä terrorisminvastaisena taisteluna. Samaan aikaan se on kuitenkin myös yksi 2000-luvun suurimmista humanitaarisista katastrofeista, jonka syntyyn ovat vaikuttaneet niin al-Assadin hallinnon siviileihin kohdistamat sotatoimet kuin myös ulkovaltojen sekaantuminen konfliktiin. Tammen mukaan Jokinen pureutuu teoksessaan Syyrian sodan juurisyihin ja tuo onnistuneesti yhteen sen poliittiset, inhimilliset ja historialliset ulottuvuudet.

Vuoden 2021 alusta eteenpäin toimituksellinen viestikapula siirtyy uudelle päätoimitukselle, jonka vastaavaksi päätoimittajaksi on valittu Katja Mäkinen (YTT, FM). Mäkinen on valtio-opin dosentti ja Musiikin, taiteen ja kulttuurin tutkimuksen laitoksen yliopistotutkija Jyväskylän yliopistossa. Mäkinen on tutkinut käsitteellisesti ja etnografisesti kulttuuripolitiikkaa, osallistavaa hallintaa sekä EU:n kansalaisuus- ja kulttuuriohjelmia. Hänen tutkimuksensa kohdistuu kansalaisuuteen, osallistumiseen, identiteetteihin, kulttuuriperintöön sekä tiloihin ja paikkoihin. Mäkinen on toiminut valtio-opin assistenttina, kulttuuripolitiikan lehtorina ja tutkijana useissa hankkeissa. Hänen tutkimusartikkelinsa julkaistiin myös väistyvän päätoimituksen kaudella numerossa 3/2019. 
Uudessa päätoimituksessa toimivat myös Miika Salo (YTM) ja Annu Perälä (YTM). Toimituspäällikkönä aloittava Salo on valtio-opin väitöskirjatutkija Tampereen yliopistossa. Hän on tutkinut valtioteoriaa, Antonio Gramscin ajattelua ja vasemmistolaisia poliittisia liikkeitä. Uuden päätoimituksen toimitussihteerinä aloittava Perälä työskentelee väitöskirjatutkijana Vaasan yliopistossa. Hänen väitöskirjansa käsittelee ilmastonmuutokseen liittyvää viestintää. Perälä on valmistunut valtio-opin maisteriksi Lapin yliopistosta vuonna 2015. Lisäksi hän on työskennellyt väitös- ja projektitutkijana Turun yliopiston Eduskuntatutkimuksen keskuksessa. Perälä on osallistunut useamman teoksen toimitustyöhön ja on aktiivinen tiedeviestijä.

Uuden päätoimituksen myötä Politiikka-lehden perinteinen rotaatio, jossa päätoimitusvastuu kiersi vuorollaan jokaisessa politiikan tutkimusta tekevässä suomalaisessa yliopistossa, päättyy. Vuonna 2021 Politiikka-lehden toimittamisessa siirrytään uudenlaiseen rotaatiojärjestelmään siten, että päätoimitus rekrytoidaan jatkossa avoimesti suomalaisen politiikan tutkimuksen tiedeyhteisöstä, ja päätoimituksen eri jäsenten kausia pyritään porrastamaan niin, että koko toimituksen tarve opetella kaikki julkaisukäytännöt teknisine työkaluineen uudelleen vähenee. Hiljainen tieto siirtyy näin helpommin päätoimitukselta toiselle.

Haluamme toivottaa tulevalle toimituskunnalle onnea ja menestystä vaativassa, mutta samalla erittäin antoisassa tehtävässä!

\section{TAPIO JUNTUNEN, MIKKO POUTANEN JA MIKKO LAHTINEN}

\section{LÄHTEET}

Ampuja, Marko ja Mikko Poutanen. 2020. Trollaus poliittisena viestintästrategiana ja liberaalin demokratian kriisioireena. Politiikasta, 11.11.2020. https://politiikasta.fi/trollaus-poliittisena-viestintastrategiana-ja-liberaalidemokratian-kriisioireena/. Viitattu 27.11.2020.

Christensen, Joel P. ja Sears Matthew A. 2018. The Overlooked Messages of the Sokal-Squared Hoax. Inside Higher ED, 30.10.2018. https://www.insidehighered.com/views/2018/10/30/sokal-squared-hoaxwas-put-down-scholars-concerned-racial-issues-opinion. Viitattu 25.11.2020.

Epstein, William M. 1990. Confirmational Response Bias among Social Work Journals. Science, Technology, \& Human Values 15:1, 9-38. https://doi.org/10.1177/016224399001500102.

Flaherty, Colleen. 2019. Blowback Against a Hoax. Insiude Higher ED, 8.1.2019. https://www.insidehighered.com/news/2019/01/08/author-recent-academic-hoax-faces-disciplinary-action-portland-state. Viitattu 27.11.2020.

Halme, Panu. 2020. Saako tutkija tuntea? Koneen Säätiön Rohkeus-blogi, 3.9.2020. https://koneensaatio. fi/saako-tutkija-tuntea/. Viitattu 3.12.2020.

Harni, Esko. 2020. Tutkijoiden uhkailijat ovat usein oikeistopopulisteja. Yliopisto-lehti 2.11.2020. https:// www.helsinki.fi/fi/uutiset/talous-yhteiskunta/tutkijoiden-uhkailijat-ovat-usein-oikeistopopulisteja. Viitattu 2.12.2020.

Haukkala, Hiski. 2019. Täydellinen tutkija? Turbulentin maailman ja kansainvälisen politiikan välisestä suhteesta. Politiikka 61:1, 75-80.

Juntunen, Tapio ja Hyvönen Ari-Elmeri. 2020. Koronakriisi, informaatio ja resilienssipolitiikka. 
Kosmopolis 50:2, 72-92.

Juntunen, Tapio, Poutanen, Mikko ja Lahtinen Mikko. 2019. Ilmastokriisi sukupolvikokemuksena? Politiikka 61:3, 186-191.

Kostiainen, Aura. 2020. Tutkijuuden ja politiikan yhdistämisen vaikeus ja hienous. Koneen Säätiön Rohkeus-blogi 16.1.2020. https://koneensaatio.fi/tutkijuuden-ja-politiikan-yhdistamisen-vaikeus-jahienous/. Viitattu 3.12.2020.

Lagerspetz, Mikko. 2020/tulossa. “The Grievance Studies Affair” Project: Reconstructing and Assessing the Experimental Design. Science, Technology, \& Human Values. https://doi.org/10.1177/0162243920923087.

Lahtinen, Mikko. 2019. Mihin yliopistokritiikki hävisi yliopistoista? Politiikka 61:4, 281-286.

Launis, Veikko. 2006. Tieteellinen huijaus. Tieteessä tapahtuu 24:4, 29-31.

Lăzăroiu, George. 2019. Postmodernist sophistry, shoddy peer review, and academic dishonesty: How subjective science knowledge and patience for nonsense may cause (pseudo-)scholarly hoax. Boghossian et al. affair. Educational Philosophy and Theory 51:14, 1408-1412. https://doi.org/10.1080/00131857.2019.1590791.

Manneström, Rasmus, Muotka, Joona, Leikas, Sointu ja Lönnqvist Jan-Erik. 2020. Hyvin toimeentuleva, terve ja suvaitsematon - suomalaisten nuorten poliittiset ideologiat asenneprofileina tarkasteltuna. Politiikka 62:1, 9-32. https://doi.org/10.37452/politiikka.83247.

Poutanen, Mikko J., Juntunen, Tapio ja Lahtinen Mikko. 2019a. Uusi toimitus, uusi julkaisutapa. Politiikka 61:1, 1-5.

Poutanen, Mikko J., Juntunen, Tapio ja Lahtinen Mikko. 2019b. Muuttuva Yliopisto. Politiikka 61:2, 99-102.

Poutanen, Mikko J., Juntunen, Tapio ja Lahtinen Mikko. 2020. Tutkija ja tiede suomalaisessa yhteiskunnassa vuonna 2020. Politiikka 61:2, 3-8. https://doi.org/10.37452/politiikka.91139.

Schnabel, Jim. 1994. Puck in the Laboratory: The Construction and Deconstruction of Hoaxlike Deception in Science. Science, Technology \& Human Values 19:4, 459-492.

Seuri, Allan ja Vartiainen Hannu. 2018. Yliopistojen rahoitus, kannustimet ja rakennekehitys. Kansantaloudellinen aikakauskirja 1:114, 100-131.

Seuri, Olli ja Poutanen Mikko. 2020. Tutkija ja journalisti - Tiedon ja yhteiskunnallisen vaikuttamisen yhteiset rajapinnat. Politiikasta 18.11.2020. https://politiikasta.fi/tutkija-ja-journalisti-tiedon-ja-yhteiskunnallisen-vaikuttamisen-yhteiset-rajapinnat/. Viitattu 3.12.2020.

Tutkimuseettinen neuvottelukunta. 2013. Hyvä tieteellinen käytäntö ja sen loukkausepäilyjen käsitteleminen Suomessa. https://tenk.fi/sites/tenk.fi/files/HTK_ohje_2012.pdf. Viitattu 27.11.2020.

Vogt, Henri. 2019. Euroopan unioni pitkäjänteisen politiikan tekijänä. Politiikka 61:4, 364-375.

Vuori, Juha. 2016. Tuomiopäivästä humanitaarisiin vaikutuksiin: ydinaseiden vastainen turvallisuuspuhe turvallistamisteorian näkökulmasta. Kosmopolis 46:1, 45-65.

Väliverronen, Esa. 2020. Tieteen vastaisku: Näkökulmia tieteen ja politiikan suhteeseen. Politiikasta 30.11.2020. https://politiikasta.fi/tieteen-vastaisku-nakokulmia-tieteen-ja-politiikan-suhteeseen/ . Viitattu 2.12.2020.

Väliverronen, Esa ja Ekholm Kai (toim.). 2020. Tieteen vapaus \& Tutkijan sananvapaus. Tampere: Vastapaino.

Väliverronen, Esa ja Saikkonen Sampsa. 2020. "Tutkijat vaikenevat itsesuojeluvaistonsa perusteella" kokemuksia tieteen vapauden ja sananvapauden uhkista. Teoksessa Esa Väliverronen ja Kai Ekholm (toim.), Tieteen vapaus \& Tutkijan sananvapaus. Tampere: Vastapaino, 283-318. 